\title{
Bis(ammonium) Zoledronate Dihydrate
}

\author{
Małgorzata Sikorska and Jarosław Chojnacki \\ Department of Chemistry, Gdańsk University of Technology, G. Narutowicza 11/12, 80233 Gdańsk, Poland \\ Correspondence should be addressed to Jarosław Chojnacki; jarekch@pg.gda.pl
}

Received 23 April 2013; Accepted 27 August 2013

Academic Editors: M. Du, P. Macchi, and Y. Xu

Copyright (C) 2013 M. Sikorska and J. Chojnacki. This is an open access article distributed under the Creative Commons Attribution License, which permits unrestricted use, distribution, and reproduction in any medium, provided the original work is properly cited.

Neutralization of 2-(1-imidazole)-1-hydroxyl-1,1' -ethylidenediphosphonic acid (zoledronic acid) by an excess of ammonia yielded bis(ammonium) zoledronate dihydrate, $\left\{\mathrm{C}_{5} \mathrm{H}_{8} \mathrm{~N}_{2} \mathrm{O}_{7} \mathrm{P}_{2}{ }^{2-}, 2\left(\mathrm{H}_{4} \mathrm{~N}^{+}\right), 2\left(\mathrm{H}_{2} \mathrm{O}\right)\right\}$. The product is readily soluble in water and forms monocrystals for which the X-ray structural analysis was carried out. The zoledronic anion is of double negative charge due to deprotonation of three $\mathrm{P}-\mathrm{OH}$ groups and protonation of the nitrogen in the imidazole ring. The structure is stabilized by extensive network of $\mathrm{N}-\mathrm{H} \cdots \mathrm{O}$ and $\mathrm{O}-\mathrm{H} \cdots \mathrm{O}$ hydrogen bonds expanding through the crystal in plane (002). The imidazole ring is involved in $\pi-\pi$ stacking interactions with its symmetry equivalents related by inversion centers at $\left(\begin{array}{llll}1 & 0 & 0\end{array}\right)$ and $\left(\begin{array}{lll}1 & 1 / 2 & 0\end{array}\right)$, with distances between centroids $(\mathrm{Cg}-\mathrm{Cg})$ of 3.819 (2) and 3.881 (2) $\AA$, respectively.

\section{Introduction}

Bisphosphonates have been subject of intensive research mainly due to their application in medicine as bone resorption inhibitors [1]. 2-(1-Imidazole)-1-hydroxyl-1,1' ethylidenediphosphonic acid, known as zoledronic acid, is regarded as the third generation of drugs for osteoporosis. Due to its structure, imidazolyl $-\mathrm{CH}_{2}-\mathrm{C}(\mathrm{OH})\left\{\mathrm{O}=\mathrm{P}(\mathrm{OH})_{2}\right\}_{2}$, the acid may be deprotonated at all four $\mathrm{P}-\mathrm{OH}$ groups and protonated at the imidazolic $\mathrm{N}$ atom. The kind of the ion formed should influence not only coordination mode and intermolecular interactions but also the water solubility of the product, which may alter bioavailability.

Salts of zoledronic acid in the solid state usually contain monovalent anion resulting from deprotonation of two $\mathrm{OH}$ groups and protonation of the imidazole nitrogen. Examples include salts of sodium $\mathrm{Na}^{+} \cdot \mathrm{C}_{5} \mathrm{H}_{9} \mathrm{~N}_{2} \mathrm{O}_{7} \mathrm{P}_{2}{ }^{-} \cdot 4 \mathrm{H}_{2} \mathrm{O}$ [3] and a series of compounds of general formula $\left(\mathrm{C}_{5} \mathrm{H}_{9} \mathrm{~N}_{2} \mathrm{O}_{7} \mathrm{P}_{2}^{-}\right)_{2} \mathrm{M}\left(\mathrm{H}_{2} \mathrm{O}\right)_{2} \mathrm{M}=\mathrm{Mg}$ [4], $\mathrm{Zn}$ [5], Mn [6], $\mathrm{Cu}$ [7], $\mathrm{Co}$, and $\mathrm{Ni}$ [8]. In some cases (for $\mathrm{Cu}, \mathrm{Co}, \mathrm{Mn}$, and $\mathrm{Ni}$ ), polynuclear complexes or coordination polymers are formed, with potentially interesting magnetic properties (e.g., [9]). Doubly negative anion was encountered in the catena $\left(\left(\mu_{3}\right.\right.$-zoledronato)aqua calcium $)$ [10]. Triply negative anion was found in a tris(dicyclohexylammonium) zoledronate ethanol solvate monohydrate [11]. It is one of the few structures reported with nonprotonated imidazole ring.
The other two are the cobalt derivative with coordination of the ring nitrogen to a metal atom Co $\cdots \mathrm{N}$ [9] and the mentioned above calcium salt [10]. Structure of another organic ammonium salt of the acid was recently reported (albeit with mononegative anion) - cytosinium zoledronate trihydrate [12]. In this paper, we carried out neutralization of zoledronic acid with excess of ammonia to reveal whether mono-, bis-, or trisammonium salt will be formed in the solid state and to study the basic properties and the structure of the obtained product.

\section{Materials and Methods}

Starting material 2-(1-imidazole)-1-hydroxyl-1,1'-ethylidenediphosphonic acid monohydrate (zoledronic acid monohydrate) was supplied by Polpharma SA (Starogard Gdanski, Poland) and used as such (m.p. $239^{\circ} \mathrm{C}$ ). Other reagents were of analytical grade and were used without further workup.

2.1. Synthesis. Preparation of $\mathrm{C}_{5} \mathrm{H}_{20} \mathrm{~N}_{4} \mathrm{O}_{9} \mathrm{P}_{2}$ is given as follows. Solution of $3 \mathrm{~mol} / \mathrm{dm}^{3}$ ammonia (eight-fold excess, $0.86 \mathrm{~mL}, 2.6 \mathrm{mmol}$ ) and solid zoledronic acid $(88 \mathrm{mg}$, $0.325 \mathrm{mmol})$ were added to a mixture of water $(8 \mathrm{~mL})$ and ethanol $(4 \mathrm{~mL})$. The contents were stirred and heated to boiling. The solution was concentrated under vacuum to ca 
TABLE 1: Crystal data, data collection, and refinement details for $\mathrm{C}_{5} \mathrm{H}_{8} \mathrm{~N}_{2} \mathrm{O}_{7} \mathrm{P}_{2}{ }^{2-} \cdot 2\left(\mathrm{H}_{2} \mathrm{O}\right) \cdot 2\left(\mathrm{H}_{4} \mathrm{~N}^{+}\right)$.

\begin{tabular}{|c|c|}
\hline Empirical formula & $\mathrm{C}_{5} \mathrm{H}_{20} \mathrm{~N}_{4} \mathrm{O}_{9} \mathrm{P}_{2}$ \\
\hline Formula weight & 342.19 \\
\hline Crystal system & Triclinic \\
\hline Space group & $P \overline{1}$ \\
\hline Temperature & $293 \mathrm{~K}$ \\
\hline Wavelength & $0.71073 \AA$ \\
\hline \multirow{6}{*}{ Unit cell dimensions } & $a=6.8415(4) \AA$ \\
\hline & $b=7.5070(5) \AA$ \\
\hline & $c=13.9398(10) \AA$ \\
\hline & $\alpha=81.735(6)^{\circ}$ \\
\hline & $\beta=82.922(5)^{\circ}$ \\
\hline & $\gamma=82.780(5)^{\circ}$ \\
\hline Volume & $698.84(8) \AA^{3}$ \\
\hline$Z$ & 2 \\
\hline Density (calcd.) & $1.626 \mathrm{Mg} \mathrm{m}^{-3}$ \\
\hline Absorption coeff. & $\mu=0.36 \mathrm{~mm}^{-1}$ \\
\hline$F(000)$ & 360 \\
\hline Crystal size & $0.45 \times 0.12 \times 0.08 \mathrm{~mm}$ \\
\hline Crystal color and shape & Colorless, block \\
\hline$\theta$ range data collection & $\theta=2.8-25.1^{\circ}$ \\
\hline \multirow{3}{*}{ Limiting indices } & $h=-5 \rightarrow 8$ \\
\hline & $k=-8 \rightarrow 8$ \\
\hline & $l=-16 \rightarrow 15$ \\
\hline Reflections collected & 3930 \\
\hline Independent reflections & $2481\left(R_{\mathrm{int}}=0.023\right)$ \\
\hline Refinement method & Full-matrix least-square on $F^{2}$ \\
\hline Data/restraints/parameters & $2481 / 14 / 235$ \\
\hline Goodness-of-fit on $F^{2}$ & 1.07 \\
\hline Final $R$ indices $[I>2 \sigma(I)]$ & $\begin{array}{c}R_{1}=0.0481 \\
w R\left(F^{2}\right)=0.1153\end{array}$ \\
\hline$R$ indices (all data) & $\begin{array}{c}R_{1}=0.0586 \\
w R\left(F^{2}\right)=0.1279\end{array}$ \\
\hline Residual el. density & $\begin{array}{c}\Delta \rho_{\max }=0.49 \mathrm{e} \AA^{-3} \\
\Delta \rho_{\min }=-0.34 \mathrm{e} \AA^{-3}\end{array}$ \\
\hline
\end{tabular}

$2 \mathrm{~mL}$ and left to crystallize by slow evaporation, and after, a few days, colorless crystals (m.p. 260-261 ${ }^{\circ} \mathrm{C}$ ) suitable for Xray diffraction were obtained.

Elemental analysis, CHNS, found the following (calculated for $\mathrm{C}_{5} \mathrm{H}_{20} \mathrm{~N}_{4} \mathrm{O}_{9} \mathrm{P}_{2}$ ): $\mathrm{C} 17.73 \%$ (17.55), $\mathrm{H} 5.75 \%$ (5.89), $\mathrm{N}$ $16.01 \%$ (16.37), and S 0\% (0). Apparatus used is Vario El Cube CHNS (Elementar).

2.2. X-Ray Crystallography. Diffraction data were collected using KM4CCD (Kuma), Sapphire2, large Be window, 4-axis kappa diffractometer with graphite monochromator, and Mo $\mathrm{K}_{\alpha}$ radiation, at ambient temperature. More details are given in Table 1.

Structure was refined with all heavy atoms treated as anisotropic and $\mathrm{H}$-atoms as isotropic. All $\mathrm{C}-\mathrm{H}$ and $\mathrm{C}-\mathrm{OH}$ hydrogen atoms were refined as riding on their bonded counterpart atoms with the usual constrains. Hydrogen atoms

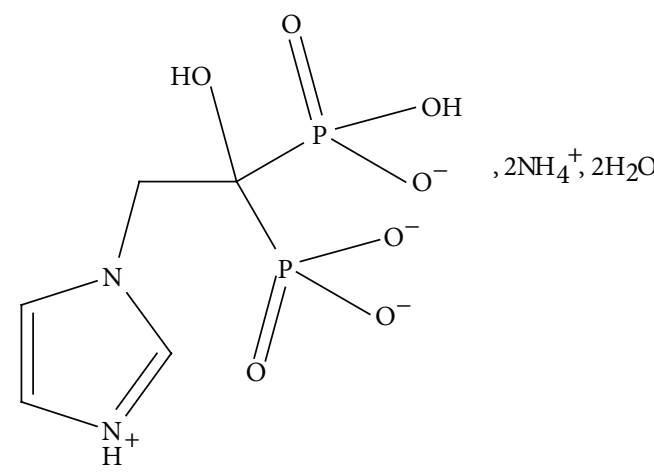

SCHEME 1

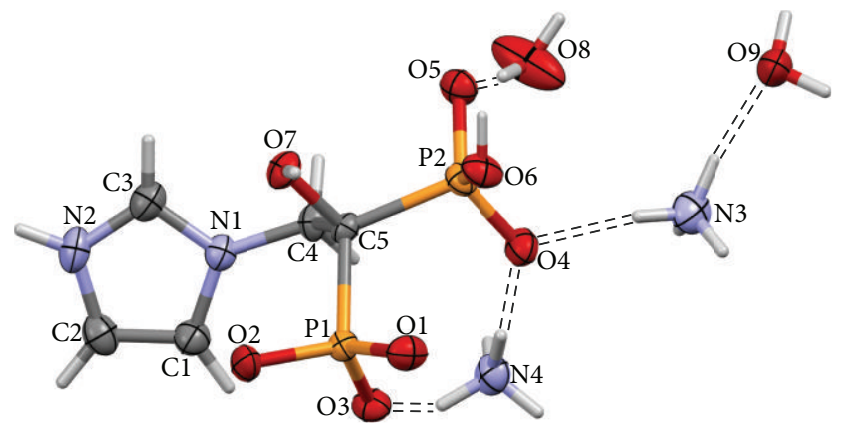

Figure 1: Molecular structure of $\mathrm{C}_{5} \mathrm{H}_{20} \mathrm{~N}_{4} \mathrm{O}_{9} \mathrm{P}_{2}$ showing atom labeling scheme. All hanging hydrogen bonds are not shown; displacement ellipsoids $50 \%$.

belonging to water molecules were found in the Fourier map and refined with $\mathrm{O}-\mathrm{H}$ bond length constrained to $0.82 \AA$. The same location method was applied to the $\mathrm{H}$ atoms bound to ammonium nitrogen atoms, whose $\mathrm{N}-\mathrm{H}$ distances were constrained to $0.86 \AA$. Hydrogen atom at $\mathrm{O} 6$ was found in the electron density map and refined as riding on the oxygen atom.

Programs used are the following: for data collection, CrysAlis PRO (Agilent Technologies) [13]; for cell refinement and data reduction, CrysAlis PRO [13]; for solving structure, SUPERFLIP [14]; for refineing structure, SHELXL97 [15] and WinGX [16]; for molecular graphics, Mercury [17] and ORTEP-3 [18]; software used for preparing material for publication, PLATON [2], CSD [19], and publCIF [20].

Supplementary crystallographic data for $\mathrm{C}_{5} \mathrm{H}_{20} \mathrm{~N}_{4} \mathrm{O}_{9} \mathrm{P}_{2}$, CCDC 935170, can be obtained free of charge via http:// www.ccdc.cam.ac.uk/conts/retrieving.html or from the Cambridge Crystallographic Data Centre, Cambridge, UK.

\section{Results and Discussion}

Reaction of zoledronic acid with an excess of ammonia yielded the title compound: $\mathrm{C}_{5} \mathrm{H}_{8} \mathrm{~N}_{2} \mathrm{O}_{7} \mathrm{P}_{2}{ }^{2-}$. $2\left(\mathrm{H}_{4} \mathrm{~N}^{+}\right) \cdot 2\left(\mathrm{H}_{2} \mathrm{O}\right)$.

Its molecular structure is shown in Scheme 1 and Figure 1, and geometric parameters are given in Table 2 . The bisphosphonate anion is of double negative charge due to 
TABle 2: Selected geometric parameters $\left(\AA{ }^{\circ}\right)$.

\begin{tabular}{|c|c|c|c|}
\hline $\mathrm{P} 1-\mathrm{O} 1$ & $1.516(2)$ & $\mathrm{O} 7-\mathrm{C} 5$ & $1.443(3)$ \\
\hline P1-O3 & $1.526(2)$ & $\mathrm{N} 2-\mathrm{C} 3$ & $1.325(4)$ \\
\hline $\mathrm{P} 1-\mathrm{O} 2$ & $1.537(2)$ & $\mathrm{N} 2-\mathrm{C} 2$ & $1.366(4)$ \\
\hline $\mathrm{P} 1-\mathrm{C} 5$ & $1.879(3)$ & N1-C3 & $1.337(4)$ \\
\hline $\mathrm{P} 2-\mathrm{O} 4$ & $1.509(2)$ & $\mathrm{N} 1-\mathrm{Cl}$ & $1.384(4)$ \\
\hline $\mathrm{P} 2-\mathrm{O} 5$ & $1.514(2)$ & N1-C4 & $1.478(4)$ \\
\hline $\mathrm{P} 2-\mathrm{O} 6$ & $1.578(2)$ & $\mathrm{C} 1-\mathrm{C} 2$ & $1.353(5)$ \\
\hline $\mathrm{P} 2-\mathrm{C} 5$ & $1.861(3)$ & $\mathrm{C} 5-\mathrm{C} 4$ & $1.543(4)$ \\
\hline O1-P1-O3 & $112.51(12)$ & C3-N1-C1 & $108.4(3)$ \\
\hline $\mathrm{O} 1-\mathrm{P} 1-\mathrm{O} 2$ & $111.12(13)$ & C3-N1-C4 & $124.2(3)$ \\
\hline $\mathrm{O} 3-\mathrm{P} 1-\mathrm{O} 2$ & $112.06(12)$ & $\mathrm{C} 1-\mathrm{N} 1-\mathrm{C} 4$ & $127.4(2)$ \\
\hline O1-P1-C5 & $109.45(12)$ & $\mathrm{C} 2-\mathrm{C} 1-\mathrm{N} 1$ & $106.5(3)$ \\
\hline $\mathrm{O} 3-\mathrm{P} 1-\mathrm{C} 5$ & $105.41(12)$ & $\mathrm{C} 1-\mathrm{C} 2-\mathrm{N} 2$ & $107.6(3)$ \\
\hline $\mathrm{O} 2-\mathrm{P} 1-\mathrm{C} 5$ & $105.88(12)$ & $\mathrm{O} 7-\mathrm{C} 5-\mathrm{C} 4$ & $104.3(2)$ \\
\hline $\mathrm{O} 4-\mathrm{P} 2-\mathrm{O} 5$ & $116.33(13)$ & $\mathrm{O} 7-\mathrm{C} 5-\mathrm{P} 2$ & $109.87(18)$ \\
\hline $\mathrm{O} 4-\mathrm{P} 2-\mathrm{O} 6$ & $109.22(13)$ & $\mathrm{C} 4-\mathrm{C} 5-\mathrm{P} 2$ & $106.06(18)$ \\
\hline $\mathrm{O} 5-\mathrm{P} 2-\mathrm{O} 6$ & $110.01(12)$ & O7-C5-P1 & 111.87 (18) \\
\hline $\mathrm{O} 4-\mathrm{P} 2-\mathrm{C} 5$ & $107.62(12)$ & $\mathrm{C} 4-\mathrm{C} 5-\mathrm{P} 1$ & $112.52(19)$ \\
\hline O5-P2-C5 & $109.04(13)$ & $\mathrm{P} 2-\mathrm{C} 5-\mathrm{P} 1$ & $111.85(14)$ \\
\hline O6-P2-C5 & $103.87(13)$ & $\mathrm{N} 2-\mathrm{C} 3-\mathrm{N} 1$ & $108.5(3)$ \\
\hline $\mathrm{C} 3-\mathrm{N} 2-\mathrm{C} 2$ & $109.0(3)$ & $\mathrm{N} 1-\mathrm{C} 4-\mathrm{C} 5$ & $114.0(2)$ \\
\hline $\mathrm{C} 3-\mathrm{N} 1-\mathrm{C} 1-\mathrm{C} 2$ & $-0.2(3)$ & $\mathrm{O} 2-\mathrm{P} 1-\mathrm{C} 5-\mathrm{O} 7$ & $34.8(2)$ \\
\hline C4-N1-C1-C2 & $178.6(3)$ & $\mathrm{O} 1-\mathrm{P} 1-\mathrm{C} 5-\mathrm{C} 4$ & 157.95 (19) \\
\hline $\mathrm{N} 1-\mathrm{C} 1-\mathrm{C} 2-\mathrm{N} 2$ & $0.0(4)$ & $\mathrm{O} 3-\mathrm{P} 1-\mathrm{C} 5-\mathrm{C} 4$ & $36.7(2)$ \\
\hline $\mathrm{C} 3-\mathrm{N} 2-\mathrm{C} 2-\mathrm{C} 1$ & $0.2(4)$ & $\mathrm{O} 2-\mathrm{P} 1-\mathrm{C} 5-\mathrm{C} 4$ & $-82.2(2)$ \\
\hline $\mathrm{O} 4-\mathrm{P} 2-\mathrm{C} 5-\mathrm{O} 7$ & $173.78(18)$ & $\mathrm{O} 1-\mathrm{P} 1-\mathrm{C} 5-\mathrm{P} 2$ & 38.68 (18) \\
\hline $\mathrm{O} 5-\mathrm{P} 2-\mathrm{C} 5-\mathrm{O} 7$ & $-59.2(2)$ & $\mathrm{O} 3-\mathrm{P} 1-\mathrm{C} 5-\mathrm{P} 2$ & $-82.56(16)$ \\
\hline $\mathrm{O} 6-\mathrm{P} 2-\mathrm{C} 5-\mathrm{O} 7$ & $58.1(2)$ & $\mathrm{O} 2-\mathrm{P} 1-\mathrm{C} 5-\mathrm{P} 2$ & $158.53(14)$ \\
\hline $\mathrm{O} 4-\mathrm{P} 2-\mathrm{C} 5-\mathrm{C} 4$ & $-74.1(2)$ & $\mathrm{C} 2-\mathrm{N} 2-\mathrm{C} 3-\mathrm{N} 1$ & $-0.3(4)$ \\
\hline $\mathrm{O} 5-\mathrm{P} 2-\mathrm{C} 5-\mathrm{C} 4$ & $52.9(2)$ & $\mathrm{C} 1-\mathrm{N} 1-\mathrm{C} 3-\mathrm{N} 2$ & $0.3(3)$ \\
\hline $\mathrm{O} 6-\mathrm{P} 2-\mathrm{C} 5-\mathrm{C} 4$ & $170.17(18)$ & $\mathrm{C} 4-\mathrm{N} 1-\mathrm{C} 3-\mathrm{N} 2$ & $-178.6(3)$ \\
\hline $\mathrm{O} 4-\mathrm{P} 2-\mathrm{C} 5-\mathrm{P} 1$ & $48.92(17)$ & C3-N1-C4-C5 & $84.1(3)$ \\
\hline O5-P2-C5-P1 & $175.92(13)$ & $\mathrm{C} 1-\mathrm{N} 1-\mathrm{C} 4-\mathrm{C} 5$ & $-94.5(3)$ \\
\hline O6-P2-C5-P1 & $-66.81(16)$ & O7-C5-C4-N1 & $-60.4(3)$ \\
\hline O1-P1-C5-O7 & $-85.1(2)$ & $\mathrm{P} 2-\mathrm{C} 5-\mathrm{C} 4-\mathrm{N} 1$ & $-176.36(19)$ \\
\hline O3-P1-C5-O7 & $153.69(18)$ & $\mathrm{P} 1-\mathrm{C} 5-\mathrm{C} 4-\mathrm{N} 1$ & $61.1(3)$ \\
\hline
\end{tabular}

deprotonation of three $\mathrm{P}-\mathrm{OH}$ groups and protonation of the nitrogen in the imidazole ring. The longest $\mathrm{P}-\mathrm{O}$ bond is noted for the only $\mathrm{P}-\mathrm{OH}$ group (at $\mathrm{O} 6$ atom). Contrary to tris(dicyclohexylammonium) zoledronate [11], no intramolecular $\mathrm{P}-\mathrm{OH} \cdots \mathrm{O}$ hydrogen bond was formed. Protonation at the ring nitrogen $\mathrm{N} 2$ is confirmed by location of $\mathrm{H} 2 \mathrm{~N}$ from the electron density peak in the Fourier map. Presence of a strong hydrogen bond N2-H2N $\cdots \mathrm{O}^{\mathrm{v}}$ (charge assisted, see Table 3 ) is an additional evidence of the protonation.

It is worthy noting that $\mathrm{P} 1-\mathrm{O} 2$ bond is longer than other $\mathrm{P} 1-\mathrm{O}$ bonds probably due to the mentioned hydrogen bond. Analysis of Table 3 reveals that it is a bond with the second smallest $\mathrm{H} \cdots \mathrm{A}$ distance. Even stronger is the interaction O6-H6 $\cdots \mathrm{O}^{\mathrm{i}}$, of the only phosphorus hydroxyl group with the negatively charged oxygen, forming a first-level chain $\mathrm{C}(6)$ motif passing in parallel to the $a$-axis. The hydrogen bond network is complex with most of the first-level motifs being discrete. Among the second-level graph motifs, notable is a centrosymmetric ring $\mathrm{R} 2,4(8)$ motif with four N3$\mathrm{H}$ donors and two $\mathrm{O} 9$ acceptors placed on the inversion center at $(1 / 21 / 21 / 2)$. Packing of molecules is organized in hydrophilic and hydrophobic layers parallel to the $a b$ (i.e., (001)) plane, Figure 2. The hydrogen-bonding network is present in vicinity of the planes at $z=0.5+n(n \in Z$, the set of all integers), while close to the planes at $z=0+$ $n$ dominating are the stacking interactions. The imidazole groups, involved in $\pi-\pi$ ring stacking, interact with their symmetry equivalents related by inversion centers at $\left(\begin{array}{lll}1 & 0 & 0\end{array}\right)$ and $(11 / 20)$, with $\mathrm{Cg}-\mathrm{Cg}$ distances 3.819 (2) and 3.881 (2) $\AA$, 
TABLE 3: Hydrogen-bond geometry $\left(\AA,^{\circ}\right)$.

\begin{tabular}{|c|c|c|c|c|}
\hline & $\mathrm{D}-\mathrm{H}$ & $\mathrm{H} \cdots \mathrm{A}$ & $\mathrm{D} \cdots \mathrm{A}$ & $\mathrm{D}-\mathrm{H} \cdots \mathrm{A}$ \\
\hline $\mathrm{O} 6-\mathrm{H} 6 \cdots 3^{\mathrm{i}}$ & 0.82 & 1.74 & $2.552(3)$ & 170 \\
\hline $\mathrm{O} 7-\mathrm{H} 7 \cdots \mathrm{O} 8^{\mathrm{ii}}$ & 0.82 & 1.95 & $2.699(3)$ & 151 \\
\hline $\mathrm{O} 8-\mathrm{H} 8 \mathrm{~A} \cdots \mathrm{O} 5$ & $0.81(2)$ & $1.95(2)$ & $2.751(4)$ & $168(4)$ \\
\hline $\mathrm{O} 8-\mathrm{H} 8 \mathrm{~B} \cdots \mathrm{O} 2^{\mathrm{iii}}$ & $0.80(2)$ & $2.01(2)$ & $2.806(4)$ & $171(5)$ \\
\hline O9-H9A $\cdots \mathrm{O}^{\mathrm{iii}}$ & $0.83(2)$ & $1.96(2)$ & $2.769(3)$ & $166(4)$ \\
\hline O9-H9B $\cdots \mathrm{O}^{\text {iv }}$ & $0.84(2)$ & $2.00(2)$ & $2.841(3)$ & $179(4)$ \\
\hline $\mathrm{N} 2-\mathrm{H} 2 \mathrm{~N} \cdots \mathrm{O} 2^{\mathrm{v}}$ & $0.86(2)$ & $1.77(2)$ & $2.613(3)$ & $165(4)$ \\
\hline $\mathrm{N} 3-\mathrm{H} 3 \mathrm{~A} \cdots \mathrm{O}^{\mathrm{vi}}$ & $0.88(2)$ & $1.89(2)$ & $2.761(4)$ & $168(4)$ \\
\hline $\mathrm{N} 3-\mathrm{H} 3 \mathrm{~B} \cdots \mathrm{O} 4^{\mathrm{iv}}$ & $0.86(2)$ & $2.16(3)$ & $2.968(4)$ & $156(4)$ \\
\hline $\mathrm{N} 3-\mathrm{H} 3 \mathrm{~B} \cdots \mathrm{O}^{\mathrm{iv}}$ & $0.86(2)$ & $2.61(3)$ & $3.315(4)$ & $140(4)$ \\
\hline $\mathrm{N} 3-\mathrm{H} 3 \mathrm{C} \cdots \mathrm{O} 4$ & $0.88(2)$ & $2.14(2)$ & $3.003(4)$ & $169(5)$ \\
\hline N3-H3D $\cdots$ O9 & $0.86(2)$ & $2.16(3)$ & $2.909(4)$ & $146(4)$ \\
\hline N4-H4A $\cdots$ O9 $^{\text {vii }}$ & $0.88(2)$ & $2.02(3)$ & $2.812(4)$ & $149(3)$ \\
\hline $\mathrm{N} 4-\mathrm{H} 4 \mathrm{~B} \cdots \mathrm{O} 2^{\mathrm{vi}}$ & $0.87(2)$ & $2.01(2)$ & $2.857(4)$ & $165(3)$ \\
\hline $\mathrm{N} 4-\mathrm{H} 4 \mathrm{C} \cdots \mathrm{O} 4$ & $0.88(2)$ & $2.01(2)$ & $2.893(4)$ & $179(5)$ \\
\hline $\mathrm{N} 4-\mathrm{H} 4 \mathrm{D} \cdots \mathrm{O} 5^{\mathrm{vii}}$ & $0.88(2)$ & $2.16(2)$ & $3.000(4)$ & $159(4)$ \\
\hline
\end{tabular}

TABLE 4: Ring stacking interaction parameters $\left[\AA{ }^{\circ}\right]$, calculated with PLATON program [2]. Imid = $(\mathrm{N} 1-\mathrm{C} 1-\mathrm{C} 2-\mathrm{N} 2-\mathrm{C} 3)$; all dihedral angles between rings $\alpha=0^{\circ}$ due to symmetry.

\begin{tabular}{lcccccc}
\hline Ring(I) & Ring(II) & $\mathrm{Cg}(\mathrm{I})-\mathrm{Cg}(\mathrm{II})$ & $\beta$ & $\gamma$ & CgI_perp & Slippage \\
\hline Imid & Imid $^{\mathrm{a}}$ & $3.819(2)$ & 34.20 & 34.20 & $-3.1585(16)$ & 2.147 \\
Imid & Imid $^{\mathrm{b}}$ & $3.881(2)$ & 27.64 & 27.64 & $3.4376(16)$ & 1.800
\end{tabular}

Symmetry codes: ${ }^{\mathrm{a}} 2-x,-y,-z ;{ }^{\mathrm{b}} 2-x, 1-y,-z$.

respectively; for details, see Table 4 . The title compound is very readily soluble in water.

\section{Conclusions}

Neutralization of 2-(1-imidazole)-1-hydroxyl-1,1'-ethylidenediphosphonic acid (zoledronic acid) by an excess of ammonia gives bis(ammonium) zoledronate dehydrate: $\left\{\mathrm{C}_{5} \mathrm{H}_{8} \mathrm{~N}_{2} \mathrm{O}_{7} \mathrm{P}_{2}{ }^{2-}, 2\left(\mathrm{H}_{4} \mathrm{~N}^{+}\right), 2\left(\mathrm{H}_{2} \mathrm{O}\right)\right\}$. Crystals are readily soluble in water. The anion is of double negative charge due to deprotonation of three $\mathrm{OH}$ groups and protonation of the nitrogen atom in the imidazole ring. The structure is stabilized by extensive network of $\mathrm{N}-\mathrm{H} \cdots \mathrm{O}$ and $\mathrm{O}-\mathrm{H} \cdots \mathrm{O}$ hydrogen bonds and $\pi-\pi$ stacking interactions between the imidazole rings.

\section{Conflict of Interests}

The authors have no conflict of interests with the mentioned commercial entity.

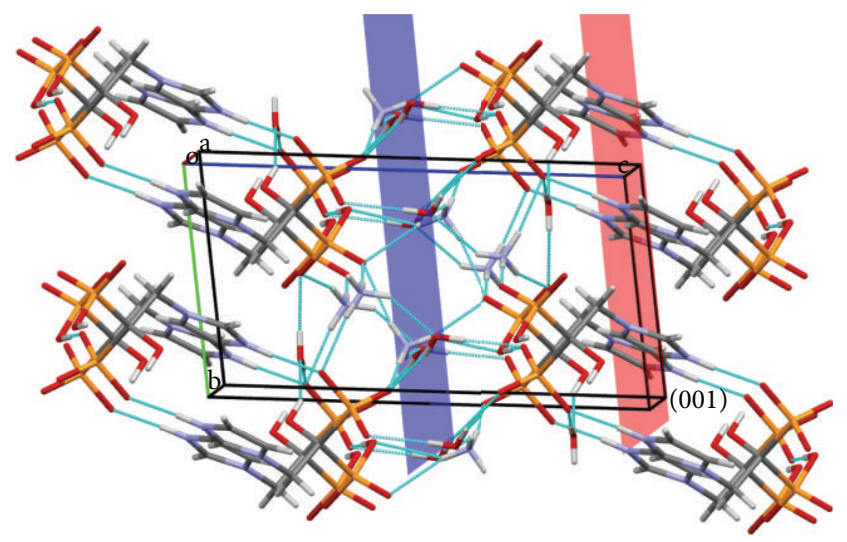

FIGURE 2: Layers of hydrogen bonding, about $a b$ plane at $z=1 / 2$ (blue) and ring stacking in vicinity of the plane at $z=1$ (pink) in the crystals of bis(ammonium) zoledronate dehydrate.

\section{Acknowledgment}

The authors thank the Polpharma SA Company (Starogard Gdanski, Poland) for the donation of samples of 2-(1imidazole)-1-hydroxyl-1,1'-ethylidenediphosphonic acid monohydrate (zoledronic acid monohydrate).

\section{References}

[1] R. G. G. Russell, "Bisphosphonates: the first 40 years," Bone, vol. 49, no. 1, pp. 2-19, 2011.

[2] A. L. Spek, "Single-crystal structure validation with the program PLATON," Journal of Applied Crystallography, vol. 36, Part 1, pp. 7-13, 2003.

[3] W. L. Gossman, Wilson, S. R. ldfield, and E. Oldfield, "Monosodium [1-hydroxy-2-(1H-imidazol-3-ium-4-yl)ethane1,1-diyl]bis(phosphonate) tetrahydrate (monosodium isozoledronate)," Acta Crystallographica C, vol. 58, pp. m599-m600, 2002.

[4] E. Freire, D. R. Vega, and R. Baggio, "Zoledronate complexes. III. Two zoledronate complexes with alkaline earth metals: $\left[\mathrm{Mg}\left(\mathrm{C}_{5} \mathrm{H}_{9} \mathrm{~N}_{2} \mathrm{O}_{7} \mathrm{P}_{2}\right) 2\left(\mathrm{H}_{2} \mathrm{O}\right)_{2}\right]$ and $\left[\mathrm{Ca}\left(\mathrm{C}_{5} \mathrm{H}_{8} \mathrm{~N}_{2} \mathrm{O}_{7} \mathrm{P}_{2}\right)\left(\mathrm{H}_{2} \mathrm{O}\right)\right]_{n}$, Acta Crystallographica, vol. C66, pp. m166-mi70, 2010.

[5] E. Freire and D. R. Vega, "Diaquabis[1-hydroxy-2-(imidazol-3ium-1-yl)-1,1' -ethylidenediphosphonato $\kappa^{2} O, O^{\prime}$ ]zinc(II)," Acta Crystallographica E, vol. 65, pp. m1428-m1429, 2009.

[6] Z.-C. Zhang, R.-Q. Li, and Y. Zhang, "Diaquabis\{[1-hydroxy2-(1H-imidazol-3-ium-1-yl)ethane-1,1-diyl]bis(hydrogen phosphonato)\}manganese(II)," Acta Crystallographica, vol. E65, pp. m1701-m1702, 2009.

[7] D.-K. Cao, X.-J. Xie, Y.-Z. Li, and L.-M. Zheng, "Copper diphosphonates with zero-, one- and two-dimensional structures: Ferrimagnetism in layer compound $\mathrm{Cu}_{3}(\operatorname{ImhedpH})_{2}$ • $2 \mathrm{H}_{2} \mathrm{O}$ [ImhedpH4 = $\left(1-\mathrm{C}_{3} \mathrm{H}_{3} \mathrm{~N}_{2}\right) \mathrm{CH}_{2} \mathrm{C}(\mathrm{OH})\left(\mathrm{PO}_{3} \mathrm{H}_{2}\right)_{2}$ ], Dalton Transactions, no. 37, pp. 5008-5015, 2008.

[8] D.-K. Cao, Y.-Z. Li, and L.-M. Zheng, "Layered cobalt(II) and nickel(II) diphosphonates showing canted antiferromagnetism and slow relaxation behavior," Inorganic Chemistry, vol. 46, no. 18, pp. 7571-7578, 2007.

[9] D.-K. Cao, M.-J. Liu, J. Huang, S.-S. Bao, and L.-M. Zheng, "Cobalt and manganese diphosphonates with one-, two-, and 
three-dimensional structures and field-induced magnetic transitions," Inorganic Chemistry, vol. 50, no. 6, pp. 2278-2287, 2011.

[10] D. Liu, S. A. Kramer, R. C. Huxford-Phillips, S. Wang, J. Della Rocca, and W. Lin, "Coercing bisphosphonates to kill cancer cells with nanoscale coordination polymers," Chemical Communications, vol. 48, no. 21, pp. 2668-2670, 2012.

[11] A. Sarkar and I. Cukrowski, "Tris(dicyclohexylammonium) hydrogen [1-hydroxy-2-(1H-imidazol-1-yl)-1-phosphonatoethane]phosphonate ethanol monosolvate monohydrate," Acta Crystallographicaaphica E, vol. 67, no. 11, p. o2980, 2011.

[12] B. Sridhar and K. Ravikumar, "Multiple hydrogen bonds in cytosinium zoledronate trihydrate," Acta Crystallographicaaphica C, vol. 67, no. 3, pp. ol15-o119, 2011.

[13] Agilent Technologies, “CrysAlis PRO," version 1. 171. 35. 15. Yarnton, England, 2011.

[14] L. Palatinus and G. Chapuis, "SUPERFLIP_a computer program for the solution of crystal structures by charge flipping in arbitrary dimensions," Journal of Applied Crystallography, vol. 40, no. 4, pp. 786-790, 2007.

[15] G. M. Sheldrick, "A short history of SHELX," Acta Crystallographica A, vol. 64, part 1, pp. 112-122, 2008.

[16] L. J. Farrugia, "WinGX suite for small-molecule single-crystal crystallography," Journal of Applied Crystallography, vol. 32 Part 4, pp. 837-838, 1999.

[17] C. F. Macrae, P. R. Edgington, P. McCabe et al., "Mercury: visualization and analysis of crystal structures," Journal of Applied Crystallography, vol. 39, no. 3, pp. 453-457, 2006.

[18] L. J. Farrugia, "ORTEP-3 for Windows-a version of ORTEPIII with a Graphical User Interface (GUI)," Journal of Applied Crystallography, vol. 30, part 5, p. 565, 1997.

[19] F. R. Allen, "The Cambridge Structural Database: a quarter of a million crystal structures and rising," Acta Crystallographica B, vol. 58 Part 3, pp. 380-388, 2002.

[20] S. P. Westrip, "PublCIF: software for editing, validating and formatting crystallographic information files," Journal of Applied Crystallography, vol. 43, no. 4, pp. 920-925, 2010. 

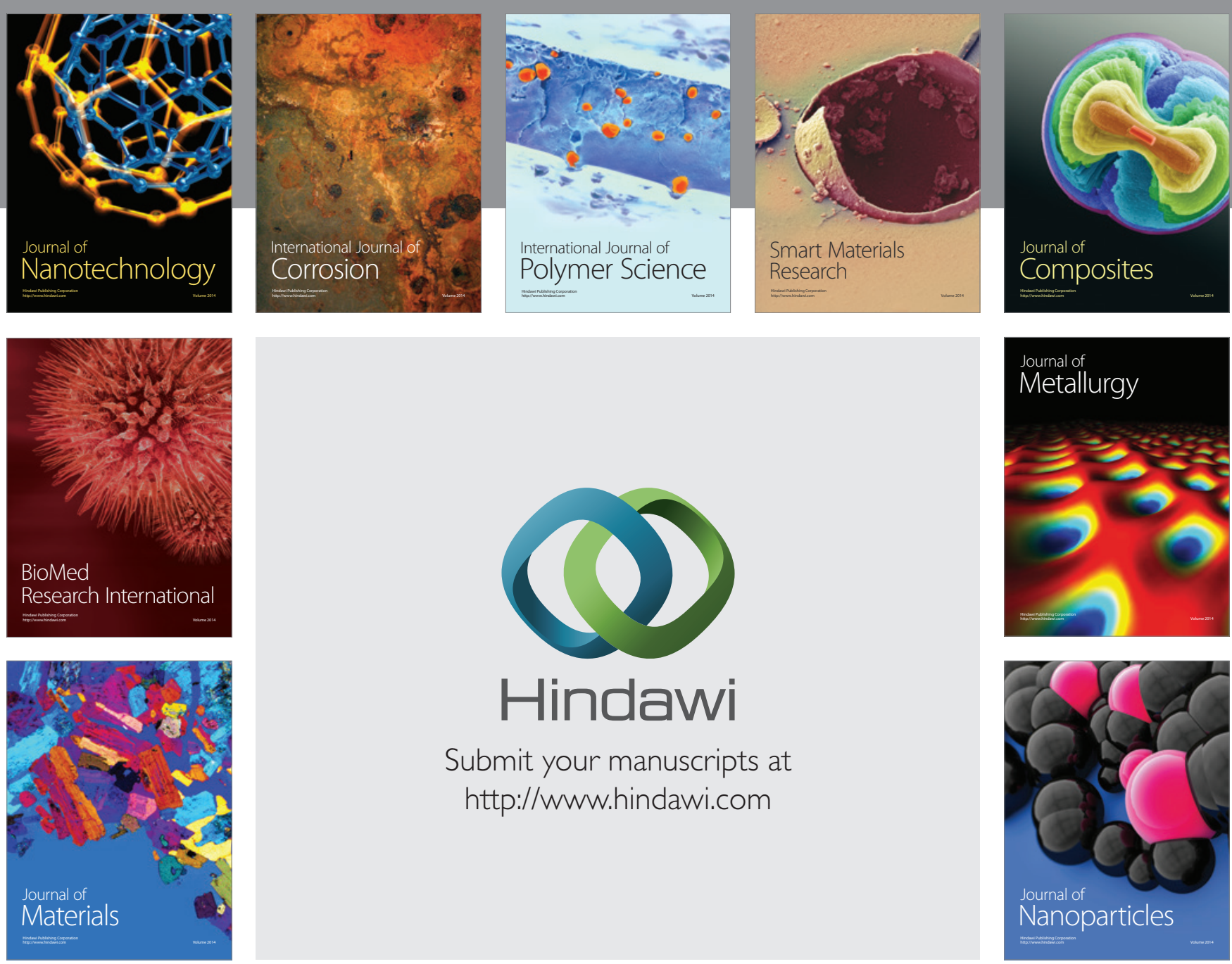

Submit your manuscripts at http://www.hindawi.com
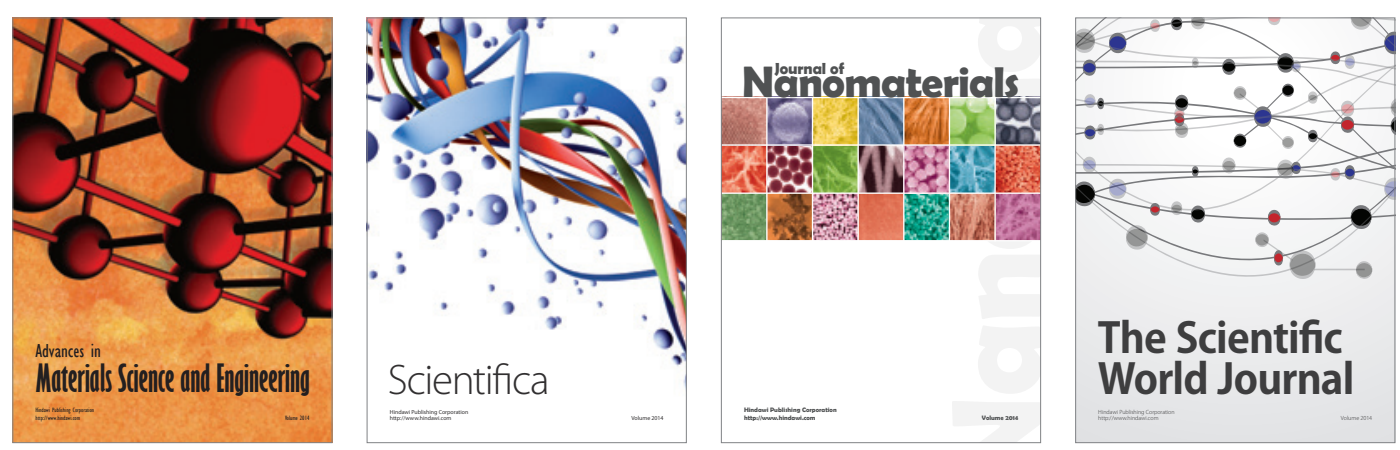

\section{The Scientific World Journal}
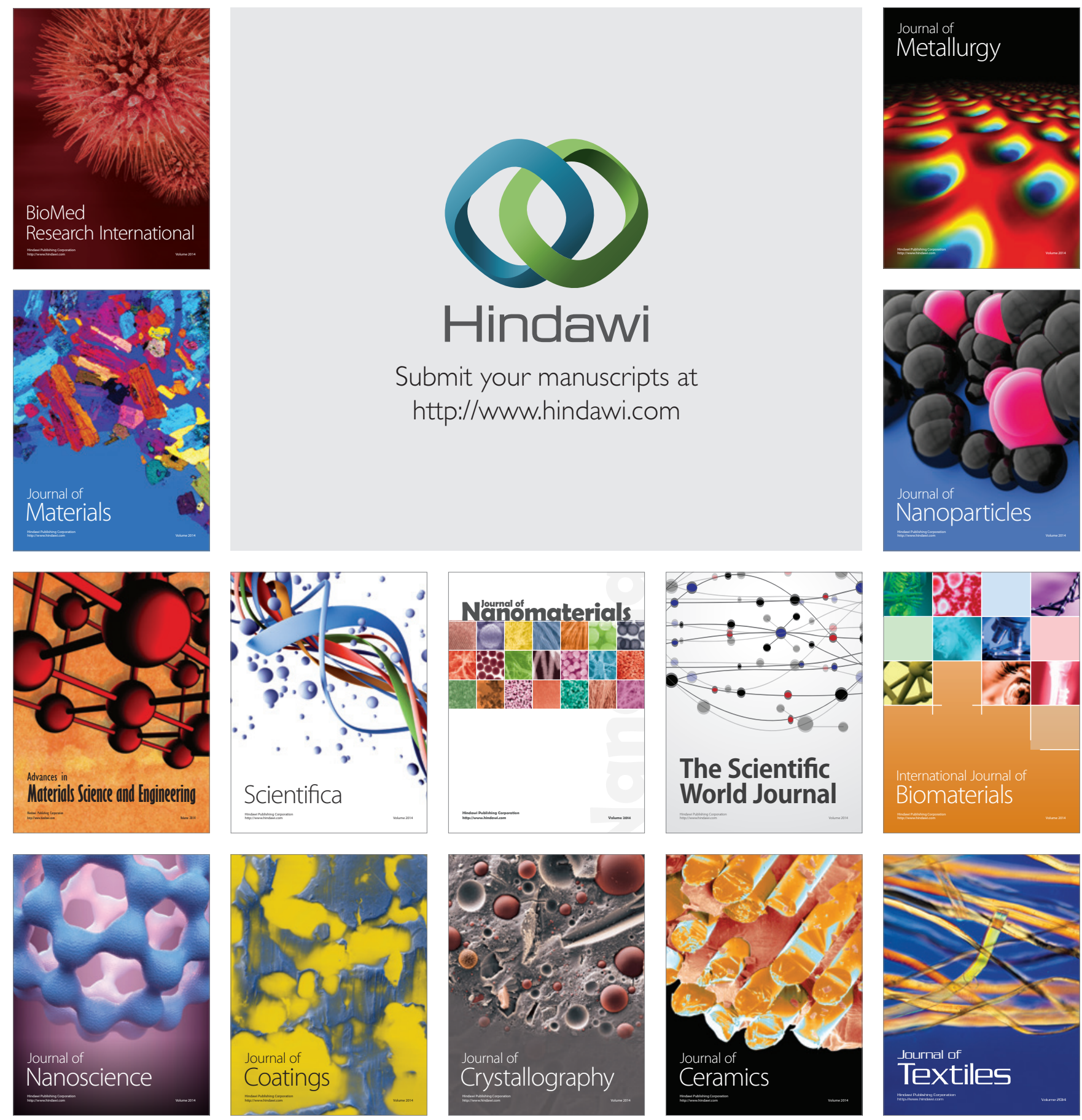